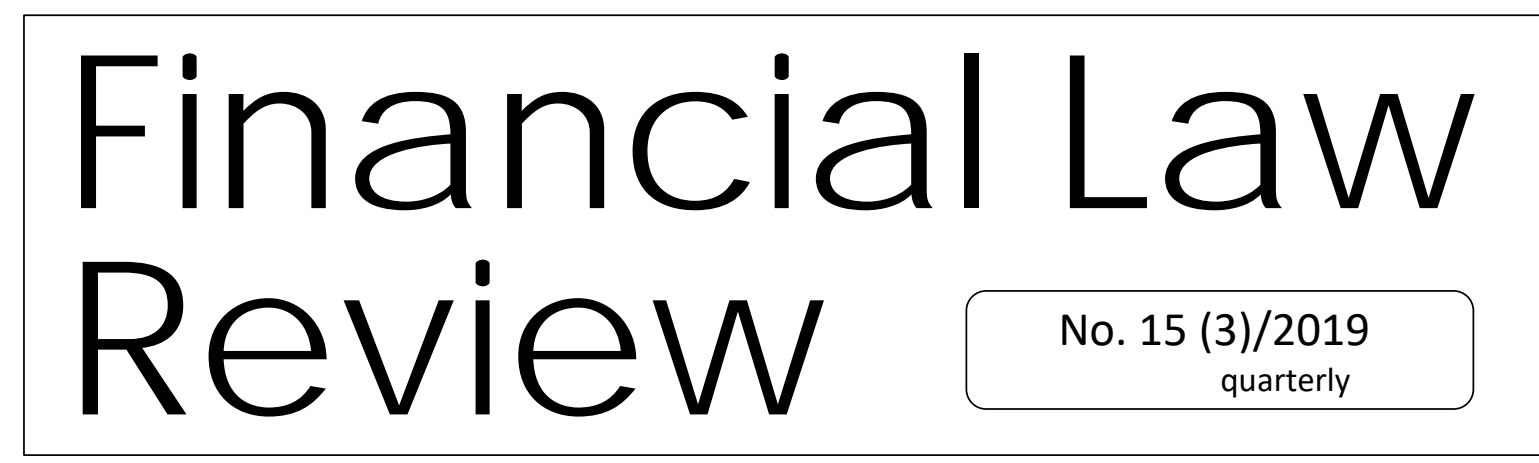

UNIVERSITY OF GDAŃSK • MASARYK UNIVERSITY • PAVEL JOZEF ŠAFÁRIK UNIVERSITY • UNIVERSITY OF VORONEZH http://www.ejoumals.eu/FLR

\title{
HOW TO REDUCE COSTS OF LOCAL TAX COLLECTION LEONARDETEL*
}

\begin{abstract}
Costs connected with the assessment and the collection of local taxes are relatively high in relation to the income therefrom. This publication discusses the ways of reducing the costs provided in the bill of new tax ordinance, which will soon be introduced in Poland. Polish experiences in this matter are of universal nature and may be used in other countries as well. The costs in point may be reduced, for example, through simplifying tax procedures and combating their excessive duration, reducing the number of assessment decisions, implementing mediation and tax agreements, covering local taxes with a clause against tax evasion, spreading electronic means of communication with the taxpayer, extending the application range of audio/video techniques in tax procedures.
\end{abstract}

Key words: Local taxes, codification of general tax law, cost, municipal tax authorities JEL Classification: K340

\footnotetext{
* Professor dr hab. at the Faculty of Law of the University of Bialystok, head of the Tax Law Department. Contact email: etel@uwb.edu.pl.
} 


\section{Introduction}

One of the main aims of the new tax ordinance prepared in Poland, which regulates general tax law, is reducing the costs connected with tax collection [Etel, Popławski 2016: 15-29]. The expenses related to the functioning of the Polish tax administration are very high [Wyrzykowski, Kasprzak 2017: 84-94]. This fact cannot be undermined by the assertion that the costs of property tax collection are by principle lower in comparison with the costs generated while collecting other tax due payments [Hy, Waugh 1995: 175]. The problem is particularly visible in the case of the municipal tax administration, which collects a great number of local taxes, the sums of which are small. Not very rare are cases where the tax amount is lower than the expenses related to its collection. In effect the real income from local taxes in the local budget are of little significance in certain municipalities. This state of affairs should be changed through introducing regulations which reduce the costs connected with local tax and fee collection. The new designed tax ordinance proposes certain solutions which aim at minimizing this negative phenomenon. They are the subject of this publication and they may be a point of departure for changes in the issue under scrutiny not only in Poland but also in other countries where the problem occurs.

\section{National or local tax authorities, which should collect local taxes?}

In 1990 it was decided in Poland that local authorities would have their own tax authorities executing most of the taxes to support local budgets [Pomorski 2016: 207]. A similar situation is also in other countries [McCluskey, Plimmer 2004:17; Kruimel 1999: 244]. It is, obviously, possible to consider solutions functioning in other states, where local taxes are collected by specialized government tax services [Radvan 2012: 203; Overview: 74]. Local governments have no own tax authorities, because it is the government tax authorities which collect all the taxes making the tax system. This model has its advantages, among which the most frequently noted is the high professional standard of the employees as well as the unitary supervision over their work, which is concentrated in the Minister of Finance's hands. However, it is also possible to note its fundamental drawbacks resulting from the fact that the costs of collecting taxes which make an income of local budgets would have to be transferred upon the local government units, which would not be viable because of the low incomes obtained by certain units [Etel 2018: 373]. It is also important that the national tax authorities in principle are not interested in collecting petty local taxes, which go to local budgets [Zajazi 2009: 19-20].

The state (government) granting the local government the powers to shape local tax payments retreats from the burden of their annual service (establishing the rates, issuing assessment decisions, conducting procedures, introducing tax exemptions etc.) [Popławski 2018: 466; Dowgier 2018: 355]. It is worth noting that there are more local taxes than state 
taxes in Poland and that they are very time-consuming due to the fact that in relation to natural persons most of them come to existence after the delivery of a establishing decision. Simultaneously, incomes obtained from these payments are incomparably lower than those from state taxes paid on the basis of self-calculation (taxpayers calculates and pays in the tax themselves). Due to the aforementioned characteristics, these payments would be very inconvenient for state authorities to administer. Hence the thesis that local taxes should be collected by local tax authorities. This is confirmed by the experience of the states where such authorities work. The bill of the new tax ordinance, of which the authors of this paper are co-authors, leaves intact the currently operating model of local tax authorities, where the wójt (head of the municipality), the mayor (or president of the city) decides at first instance, whereas the municipal appeal college at second instance. Despite attempts it turned out impossible to provide municipal tax authorities with competences to collect all taxes and fees contributing to the local budget. In the current legal state in Poland certain taxes contributing to municipal budgets are collected by the national tax authorities [Burzec, Smolen 2016: 210]. These taxes are the inheritance and donation tax, the civil legal actions tax and the tax card, which are collected by the heads of Tax Offices. Despite attempts at changing this legal status in the 1990s, it has not been done yet [Brzeski 1999: 417]. This is a certain inconsistence of the legislator, who appointed municipal tax authorities but failed to transfer all local taxes to them to collect. This is justified by the fact that the structure of these taxes is characterized by a high degree of difficulty as regards the assessment and the collection of the taxes, and therefore, to collect them it is necessary to have professional staff and technological facilities. It was decided that municipal employees are not suitably prepared for dealing with "so difficult taxes". As many years' practice has shown, many more problems connected with tax assessment and collection stemmed from the rules regulating the local property tax, and despite it, no idea emerged to pass this tax to the national tax authorities. It seems that there have long been good circumstances for all the taxes making the municipal budget became the competence of municipal tax authorities [Etel 2018: 374].

\section{Should local taxes be assessed by decisions of a tax authority?}

One of the fundamental causes of high costs of local tax collection is issuing and delivering a great number of decisions establishing tax obligations. Only delivery of such a decision makes the obligation occur. This is very convenient for taxpayers-natural persons a way of the occurrence of the tax obligation, because they receive the decision including the calculated tax. Natural persons paying these taxes do not have to calculate and declare the amount of the tax themselves, which sometimes could be very troublesome due to the intricacies of the local tax law. However, it is the most costly mode of the occurrence of tax obligations. It is particularly visible at the beginning of the year, when in a municipality, on 
average, from a few to several dozen establishing decisions are issued. The costs of the annual assessment are very high and they absorb a considerable part of the incomes from the taxes collected through decision delivering. Another problem is burdening the tax authority employees with preparing of such a big number of decisions and sending them from the office. Why such a high number of establishing decisions? It results from the rule adopted in the structure of the taxes being income of municipalities: the property tax, the agricultural tax, the forest tax, according to which a tax obligation in relation to natural persons occurs on the delivery of the decision. In our opinion the number of taxpayers receiving decisions should be considerably reduced. Natural persons with the status of entrepreneur should themselves declare the amounts of these taxes, without the necessity of delivering them assessment decisions. Entrepreneurs themselves (without decisions) pay much more complicated state taxes (VAT and the income tax), which is an argument for them declaring and paying local taxes in the same way [Etel, Dowgier 2013: 124].

The taxpayer's own declaration of the tax and its paying to the account of the tax authority is undoubtedly the cheapest way of executing tax obligations. Hence, if we want to reduce the costs of tax procedures, we should increase the importance of tax declarations in the process of tax paying. Obviously, they cannot be entirely eliminated. Such costs will occur in the case of procedures aiming at, for example, issuing a tax decision which determines a tax obligation in the amount different from that declared by the taxpayer [Liska 2018: 420]. The best would be, which for various reasons is not possible to implement at the moment, eliminating from the system taxes which occur on the delivery of the assessment decision. However, it is possible, and it is provided for in the provisions of the designed new tax ordinance, to introduce solutions encouraging the taxpayer to submit the declaration and thereby to calculate the tax on their own [Etel 2018: 382].

\section{Simplified procedures and those referring to derisory amounts of tax}

A problem which negatively affects the effectiveness of local tax authorities is the necessity of carrying out tax procedures concerning low amounts of tax in obvious cases, which do not require any proceedings to take evidence [Popławski 2017: 332]. It does not make sense to conduct a formal and costly procedure in the situation where the tax amount is not disputable, the facts raise no doubts and the taxpayer wants the case to be solved as soon as possible. According to the current Polish Tax Ordinance routine cases referring to small tax amounts must be carried out on the same basis as the cases referring to considerable amounts, which by nature require a long evidence procedure. The legislator decided to change it in the bill of the new tax ordinance through introducing simplified procedures. Such procedures are deformalized and in principle must be short. They are concluded with issuing a decision, which is not justified [Babiarz, Dowgier, Etel, Filipczyk, Gurba, 
Kuśnierz, Krawczyk, Łoboda, Nikończyk, Nita, Olesińska, Pietrasz, Popławski, Rudowski, Strzelec 2015: 128]. In effect the taxpayer receives a quick decision and the tax authority has less work and lower costs of proceedings. The simplified procedure cannot be implemented without the taxpayer's consent and in problematic cases, where occur differences as regards the circumstances affecting the tax amount. In this procedure cases will be settled quickly, within the period not longer than 14 days. According to the bill, the simplification of the procedure involves the situation where there is no need for issuing and delivering a decision of its initiating, the taxpayer is not informed about the opportunity to express their opinion on the collected evidence, as well as the issued decision is not justified, unless the party demands it on the delivery of the resolution. The taxpayer has the right, on the general principles, to appeal against the decision of the wójt (head of the municipality), mayor (president of the city) to the local government appeal college and to sue to the administrative court the decision of the college. The implementation of the simplified procedure proposed in the new tax ordinance bill will streamline settling petty cases, reduce the workload of the authorities and the costs related thereto.

We are positive that the procedure of non-initiating or discontinuing of proceedings in the cases of tax amounts which do not exceed the costs of the decision delivery should be extended. There is no economic justification for a tax the amount of which is lower than the costs of its execution. Such a tax is unwanted by both the municipality and, obviously, the taxpayer. It is collected only because the tax law requires it. It is the beneficiary of the tax income should decide when it is profitable for them to collect the tax. Otherwise the taxes which have to be subsidized make a financial burden for municipalities. The aforementioned new tax ordinance bill extends the rule of non-initiating and discontinuing the proceedings for derisory amounts (up to c. 10 euros). If the tax does not exceed the derisory amount, no procedure is initiated and those already initiated are discontinued, and the taxpayer is informed by notice.

The bill provides for, taking into account the interest of municipalities with considerable income from petty obligations, competences for the municipality council of establishing the amount lower than that provided for in the law bill. In this way municipality councils will be granted an opportunity to adjust the limit of derisory amount to the specificity of a particular area [Etel et al. 2017: 439].

\section{Combating the excessive duration of procedures}

The costs of proceedings are strictly connected with their duration. According to the current provisions of law in each case of failure to settle the affair on time the tax authority is obligated to inform the taxpayer about it and to propose a new date. The problem is that 
the proposed date does not have to be ultimate and the authority may appoint another new date. This, among other factors, results in the excessive duration of the proceedings, which involves the tax authority unjustifiably prolonging the procedure without a formal infringement of the law. The taxpayer is entitled to urge but only in the case of the failure in settling the case on time (the authority's inaction). In the new tax ordinance also the excessive duration of proceedings is a basis for submitting a reminder to the higher-level body [Etel et al. 2017: 402-403]. Finding excessive duration or inaction obliges the authority to appoint an ultimate date of settling the case. The implementation of this solution will contribute to the mobilization of municipal tax authorities to quickly deal with the tax cases, especially those concerning petty local taxes. Multi-month proceedings referring to taxes of derisory amounts exposes local budgets to considerable expenses without any possibility to compensate them with the obtained incomes.

\section{Mediation and tax agreement at settling affairs referring to local taxes}

The vast majority of cases is carried out by a local tax authority according to the following scheme: inspection, initiation of the procedure, decision and execution. The taxpayer in this mode of dealing with the tax case does not speak to the authority (an official) but there occurs an exchange of letters. Under the current regulations there is no place for deformalized ways of solving tax problems, which are reduced to the taxpayer's conversation with the tax office worker and settling controversial questions. The current tax ordinance says nothing about it, which discourages both parties from taking any attempts to deal with the cases in this way. Tax office workers are even afraid of settling the case in the agreement with the taxpayer for fear of easily formulated charges of corruption. The new tax ordinance bill provides for regulations which legalize the so-called nonadministrative forms of dealing with tax affairs (mediation, tax agreement) and secure their implementation. After their introduction the office worker will be allowed to come to agreement with the taxpayer (e.g. as regards the number of instalments, by which the outstanding taxes will be paid) without an suspicion of corruption. Many cases (including tax cases) may be settled in the fastest and cheapest way through talks and not correspondence. Mediation will increase the range of amicable settling of difficult tax cases, which are the most expensive.

\section{Local taxes and the clause against tax evasion (GAAR)}

One of the problems affecting the decrease in incomes from local taxes is the aggressive tax optimization. Taxpayers avoid paying taxes through applying schemes which are legal yet artificial and contradictory to the purpose of the law, the only aim of which is gaining a tax 
benefit. This phenomenon is prevented by the clause against tax evasion. During the works on including the clause against tax evasion into the tax ordinance a great number of controversies were raised by the issue of its application in relation to local taxes and fees [Etel, Popławski 2016: 15]. However, it was not a point if municipal tax authorities should have competences to discretional application of the clause and, in effect, issuing decisions leveling the effects of the taxpayer's artificial actions, the basic aim of which is evading taxation. From the beginning, it was aptly assumed, that the clause may be applied by one body: the head of the National Fiscal Administration. The discussion concerned the problem if avoiding paying local taxes should be eliminated by this instrument. The opinions for reducing the application of the clause to national income taxes only prevailed. It was argued that the payer of a local property tax cannot escape with the real estate to a tax paradise or hide it, and thereby it does not make sense to apply the clause to these taxes. The practice showed, however, even during the discussion, that it was possible to effectively evade paying the local property tax on a big scale through creating false agreements between interconnected entities. This circumstance was decisive in the fact that the regulations included in the ordinance referring to the clause against tax evasion are fully applicable in local taxes, excluding local fees. If a municipal tax authority sees premises for applying the clause against tax evasion, it should submit a request to the head of the National Fiscal Administration as a body competent to initiate the procedure with the application of the clause. The procedure secures a real influence of municipal tax authorities on the application of the clause in reference to the taxpayers who evade paying taxes to local budgets.

\section{Delivering letters to taxpayers and their proxies}

A huge and costly problem connected with conducting tax proceedings by municipal tax authorities is the mode of communication with the taxpayer (their proxy). Because the current regulations do not include an obligation of the taxpayer's informing the tax authority about the change of their address (in the period beyond the tax procedure), the decision delivery often faces many difficulties and lengthens the procedures. Taxpayers take advantage of the gaps in legal regulations concerning deliveries, and evade paying the tax. This is relatively easy in local taxes paid by natural persons, because a failure in delivering the decision results in the lack of obligation and no interest for delay is accrued. Taxpayers who are legal persons, on the other hand, as practice shows, take advantage of the imperfect procedure of decision delivery to lengthen the proceedings until the expiry date. The problems have been noted in the new tax ordinance bill. It proposes extension of the possibility of delivering letters through electronic means of communication. In this form it will be possible to deliver letters not only professional proxies and public entities but also entrepreneurs (except microbusiness people) as well as the users of ICT systems 
(e-PUAP and the tax portal). In addition, it is proposed that the data reported in the registration notification and stored in the Central Register of Taxpayers of the National Register of Taxpayers be a basis for establishing the address of residence and the address of the headquarters for letter delivery purposes. The possibility of efficient delivery to the address in the register will increase the efficiency of deliveries and reduce the costs related thereto. The taxpayers whose addresses are not in the register, will receive letters on the basis of general rules.

\section{Extending the possibility of tax payment for the taxpayer}

Municipal taxes are often paid not by the taxpayer but other persons, and primarily by the closest family. The phenomenon is not bad in itself and does not necessarily lead to abuses; certainly not in local taxes. In the current regulations, beside the members of the closest family who can pay the tax without an amount limit, also the real owner of the object of a compulsory mortgage or a tax lien may pay the secured amount of the tax. All other persons may pay the tax for the taxpayer but only up to the amount being an equivalent of c. 200 euros. The implementation of this limit leads to interpretative problems. Therefore, the new tax ordinance bill lifts the limit and clearly states that the persons other than the taxpayer may pay not only the tax but also the tax arrears and the interest for delay which result therefrom. In this way it will be more possible to pay relatively small tax amounts by persons other than the taxpayer, which will facilitate their execution and thereby will reduce the costs.

\section{Broader use of audio/video techniques in tax procedures}

The new ordinance proposes a broader possibility of applying modern techniques of recording picture and sound, especially in evidence proceedings. Interrogations of the parties, witnesses, experts, the hearing, inspection and other procedural activities carried out in a traditional way should be registered (audio/video). This will allow for increasing the credibility of the evidence and will more faithfully reflect the course of the actions, which will allow us to objectivize the assessment of its performance by the appeal body or the court. This will minimize disputes on the matter, will accelerate evidence activities and increase the effectiveness of the authority's work. Carriers recording the accomplished activities attached to the case files will make an alternative for written minutes of the interrogation or inspection. The actual justification of a decision it will be enough to point at an appropriate part of the recording instead of quoting large contents of the evidence in process. This is of huge importance particularly in the procedures concerning small tax amounts, which is characteristic of local taxes and fees. 


\section{Conclusion}

In conclusion it is important to state that implementing the regulations proposed in the tax ordinance bill will certainly contribute to reducing the costs of collecting local taxes and fees. In this way, incomes from local taxes contributing to local budgets will increase. Local taxes should be collected by local tax authorities. Entrusting this function to national (state) tax authorities will not contribute to the reduction of the costs of tax collection. The problems are excessive and formalized procedures carried out by local authorities. Proceedings concerning considerable tax amounts are conducted on the basis of the same rules as in the case of "derisory" payments. This results in the situation where municipal tax authorities are heavily burdened with petty cases, whereby they have less time to conduct procedures concerning considerable amounts. Also costs borne in connection with meeting all procedural requirements resulting from the regulations are of importance. The problem will be solved on implementing simplified procedures and those referring to derisory tax amounts, designed in the ordinance. A typical tax procedure in local taxes requires a delivery of at least three letters addressed to the taxpayer (a decision on initiating the procedure, a notification on the opportunity to express one's opinion on the evidence gathered, and a decision). In effect, sometimes costs of delivering the letters are higher than the tax amount. What is the point in a tax lower than the cost of its collection? There should not be procedures concerning tax amounts which are lower that the costs of their acquisition, which is provided for in the new tax ordinance bill.

The reduction of procedural costs will serve to reduce the number of decisions issued by municipal tax authorities. Local taxes should be to a greater extent calculated and paid in by taxpayers themselves. This is the cheapest method of executing taxes. We should disseminate the process of communicating of the municipal tax authority with the taxpayer through the means of electronic communication. The current procedures of delivering paper letters to taxpayers, beside their expensiveness, are inefficient, which results in the municipality losing considerable tax incomes. Cost reducing may be also achieved through consensual ways of settling tax cases in the form of mediation and agreement. Instead of a many-year-long (costly) dispute, the tax authority will be allowed to communicate with the taxpayer in difficult questions and conclude an agreement.

Implementing the ways of reducing costs of local task collection presented in the publication is currently the most effective mode of increasing incomes in municipal budgets. The incomes may be augmented without raising the taxes, which is now the fundamental condition of the success of any tax reforms. 


\section{References:}

Babiarz, S., Dowgier, R, Etel, L., Filipczyk, H., Gurba, W., Kuśnierz, W., Krawczyk, I., Łoboda, M., Nikończyk, A., Nita, A., Olesińska, A., Pietrasz, P., Popławski, M., Rudowski, J., Strzelec, D., Tax Ordinance. The assumption of a new regulation, Toruński Rocznik Podatkowy [Toruń Tax Yearbook], 2015.

Brzeski, J.: Real property taxation in Poland, in: McCluskey (ed.) Property Tax: An International Comperative Review, 1999.

Burzec, M., Smoleń, P., Tax authorities in the Visegrad Group Countries. Common experience after accession in the European Union, Lublin: Wydawnictwo KUL [KUL Publishing House], 2016.

Dowgier, R., Municipal powers to grant tax preferences for entrepreneurs, (in.) Mrkývka, P., Gliniecka, J., Tomásková, E., Juchniewicz, E., Sowiński, T., Radvan, M. (eds.), The challenges of local government financing in the light of European Union regional policy. Conference Proceedings. Brno: Publications of the Masaryk University, Theoretical Series, Edition Scientia, 2018.

Etel L., Popławski M.: The history of the Polish anti-avoidance clause, in: Karasëva (Sencova), M. V. (ed.), Publičnye finansy i nalogovoe pravo: ežegodnik. Vyp. 6. Protivodejstvie ukloneniju ot uplaty nalogov v stranach Central'noj i Vostočnoj Evropy, Voronezh: Izdatel'skij dom VGU, 2016.

Etel L.: Municipal Tax Authorities: are Changes Needed? in: Mrkývka P., Gliniecka J., Tomášková E., Juchniewicz E., Sowiński T., Radvan M. (eds.), The challenges of local government financing in the light of European Union regional policy. Conference Proceedings. Brno: Publications of the Masaryk University, Theoretical Series, Edition Scientia, 2018.

Etel, L. et al.:, Nowa ordynacja podatkowa. Z prac Komisji Kodyfikacyjnej Ogólnego Prawa Podatkowego [The New Tax Ordinance. Works of the General Taxation Law Codification Committee], Białystok: Temida2, 2017.

Etel, L., Popławski, M.: The assumptions of a new tax ordinance in Poland, Public Governance, Administration and Finances Law Review in the European Union and Central and Eastern Europe, Vol. 1, No. 1, 2016.

Hy R. J., Waugh, JR. W. L.: State and local tax policies, Liberty of Congress Catalog Card Number: 94-30931, 1995.

Kruimel, J.P.: Property tax system in the Netherlands, in: McCluskey (ed.) Property Tax: An International Comperative Review, Liberty of Congress Catalog Card Number: 98-74435, 1999.

Liška, M.: Time Context of Tax Revenues in Relation with Specific Income of Municipalities, in: Mrkývka, P., Gliniecka, J., Tomášková, E., Juchniewicz, E., Sowinski, T. \& Radvan, M. (eds.) The challenges of local government financing in the light of European Union regional policy. Conference Proceedings. Brno: Publications of the Masaryk University, Theoretical Series, Edition Scientia, 2018.

McCluskey, W., Plimmer, F.: The potential for the property tax in the 2004 accession countries of central and eastern Europe, RICS Research Paper Series, Vol. 7, No. 17 2007. 
Pomorski, P.: Municipal administrator (mayor of a town, president of a city) as a selfgovernment tax authority, in: Burzec, M., Smoleń, P. (eds.), Tax authorities in the Visegrad Group countries Common experience after accession to the European Union, Lublin: Wydawnictwo KUL [KUL Publishing House], 2009.

Popławski, M., Tax Exemptions In Local Taxes as an Element of State and Local Government Tax Policies, (in.) Mrkývka P., Gliniecka J., Tomášková E., Juchniewicz E., Sowiński T., Radvan M. (eds.), The challenges of local government financing in the light of European Union regional policy. Conference Proceedings. Brno: Publications of the Masaryk University, Theoretical Series, Edition Scientia, 2018.

Popławski, M.: Direction of Changes of tax procedures in Poland (in:) Mrkývka P., Gliniecka J., Sowiński T., Radvan M. (eds.), The financial law towards challenges of XXI century. Conference proceedings, Brno: Masaryk University Press, 2017.

Radvan, M.: Místní daně [Local Taxes]. Praha: Wolters Kluwer, 2012.

Wyrzykowski W, Kasprzak P., Ocena efektywności działalności administracji podatkowej w Polsce na tle wybranych państw [The Assessment of Tax Administration's Activity in Poland as Compared with Selected States], Zeszyty Naukowe MWSE w Tarnowie [Scientific Papers of the MWSE in Tarnów], No. 1, 2017.

Zajazi, K. (ed.): Improvoment of local property tax administration in South Eastern Europe, NALAS: Network of Associations of Local Authorities of South East Europe, 2009.

\section{Internet Resources:}

Overview of the French Tax System, Direction Générale Des Finances Publiques (Public Finances Directorate General) Tax Policy Directorate, 2016.

Available at:

https://www.impots.gouv.fr/portail/files/media/1 metier/5 international/french tax system.pdf. 